\title{
KONSEP DASAR ILMU GIZI
}

\author{
DIAN YULIAWATI DARWIS
}

Universitas Islam Negeri Alauddin Makassar

Email: dianyuliawati33@gmail.com

\section{A. PENGERTIAN ILMU GIZI}

- Secara Bahasa

Ilmu yang mempelajari segala sesuatu tentang makanan dalam hubungannya dengan kesehatan optimal. Kata gizi berasal dari bahasa Arab, ghizda yang berarti makanan. Ilmu gizi juga berkaitan dengan tubuh manusia

- Secara Istilah

Zat gizi (nutrients) adalah ikatan kimia yg diperlukan tubuh untuk melakukan fungsinya, yaitu menghasilkan energi, membangun dan memelihara jaringan serta mengatur prosesproses kehidupan.

Pengertian dari ilmu gizi (nutrition science) adalah “ Ilmu yg mempelajari segala sesuatu tentang makanan dalam hubungannya dengan kesehatan optimal". Sedangkan yang disebut sebagai makanan adalah "Bahan selain obat yang mengandung zat-zat gizi dan atau unsur-unsur/ikatan kimia yang dapat diubah menjadi zat gizi oleh tubuh, yang berguna bila dimasukkan dalam tubuh”.

Makanan dan semua suplemen yang mengandung zat gizi bisa kita kategorikan sebagai makanan. Artinya yang dikatakan gizi adalah aspek yang berhubungan dengan fungsi dasar zat gizi tersebut yaitu menghasilkan energi, pertumbuhan dan pemeliharaaan jaringan, serta mengatur proses metabolisme dalam tubuh.

\section{B. TUJUAN ILMU GIZI}

Ilmu gizi tidak hanya sebatas fungsi dasar zat gizi dan kesehatan saja tetapi zat gizi sudah dihubungkan dengan kemampuan kerja, produktivitas, IQ, dan status ekonomi.Tujuan ilmu gizi sendiri adalah mencapai, memperbaiki, dan mempertahankan kesehatan tubuh melalui konsumsi makanan.

\section{FUNGSI ILMU GIZI}

- Fungsi zat gizi sebagai sumber energi untuk menggerakkan tubuh dan proses metabolisme di dalam tubuh. Sumber energ: karbohidrat, protein dan lemak mempunyai ikatan organik mengandung karbon yang dapat dibakar.

- Untuk pertumbuhan dan mempertahankan jaringan. Berfungsi sebagai pembentuk sel-sel pada jaringan tubuh. Tergolong fungsi ini: protein, lemak, vitamin dan mineral. 
- Sebagai pengatur atau regulasi proses dalam tubuh yaitu protein, vitamin, mineral dan air. Protein membentuk antibodi, protein mengatur keseimbangan air dalam tubuh. Vitamin dan mineral sebagai pengatur fungsi saraf dan otot.

\section{KONSEP DASAR ILMU GIZI}

Konsep ilmu gizi, ada beberapa istilah yaitu:

- Zat gizi (nutrients) adalah ikatan kimia yg diperlukan tubuh untuk melakukan fungsinya, yaitu menghasilkan energi, membangun dan memelihara jaringan serta mengatur prosesproses kehidupan.

- Gizi (nutrition) adalah suatu proses organisme menggunakan makanan yang dikonsumsi secara normal melalui proses digesti, absorpsi, transportasi, penyimpanan, metabolisme, dan pengeluaran zat-zat yang tidak digunakan, untuk mempertahankan kehidupan, pertumbuhan dan fungsi normal dari organ-organ, serta menghasilkan energi.

- Pangan adalah istilah umum untuk semua bahan yang dapat di jadikan makanan.

- Makanan adalah bahan selain obat yang mengandung zat-zat gizi dan atau unsur-unsur atau ikatan kimia yang dapat diubah menjadi zat gizi oleh tubuh, yang berguna bila dimasukkan ke dalam tubuh.

- Bahan makanan adalah makanan dalam keadaan mentah.

- Status gizi adalah keadaan tubuh sebagai akibat konsumsi makanan dan penggunaan zatzat gizi.

\section{E. PENYEBAB GANGgUAN GIZI}

Gangguan gizi bisa dibagi menjadi penyebab dari faktor primer dan penyebab dari faktor sekunder.

- Faktor primer maksudnya semua masalah gizi yang disebabkan susunan makanan salah, baik dalam hal kuantitas maupun kualitasnya. Faktor primer ini dapat meliputi;

- kurangnya penyediaan pangan,

- kurang baiknya distribusi pangan,

- kemiskinan, ketidaktahuan, dan

- kebiasaan makan salah.

- Faktor sekunder meliputi semua faktor yang menyebabkan zat-zat gizi tidak sampai di sel-sel tubuh setelah makanan dikonsumsi, meliputi aspek;

1.) Anatomi, contohnya pasien yang kelainan kongenital rongga mulut, tumor daerah esofagus, dan kelumpuhan otot pengunyah pada stroke;

2.) Absorbsi, misalnya pasien malabsorbsi, pasien yang mengalami infeksi usus halus (Thypus Abdominalis), dan pasien post operasi pencernaan;

3.) Metabolisme/utilisasi, misalnya pada pasien Diabetes Mellitus yang kekurangan insulin;

4.) Ekskresi, misalnya pasien yang tidak mampu mengeluarkan sisa hasil metabolisme makanan; dan

5.) Obat-obatan misalnya pasien yang mengonsumsi obat yang berinteraksi dengan makanan sehingga zat gizi tertentu tidak bisa diserap. 


\section{F. JENIS-JENIS ZAT GIZI \\ - Zat Gizi Makro}

\section{Karbohidrat}

1.) Pengertian Karbohidrat

Karbohidrat yaitu senyawa organik terdiri dari unsur karbon $(C)$, hidrogen $(H)$, dan oksigen $(\mathrm{O})$. Karbohidrat banyak terdapat pada tumbuhan dan binatang. Pada tumbuhan sintesis $\mathrm{CO} 2+\mathrm{H} 2 \mathrm{O}$ akan menghasilkan amilum / selulosa melalui proses fotosintesis. Banyak sekali makanan yang kita makan sehari-hari adalah sumber karbohidrat seperti : nasi/ beras, singkong, umbi-umbian, gandum, sagu, jagung, kentang, dan beberapa buah-buahan lainnya.

2.) Fungsi Karbohidrat

a. Sebagai Sumber Energi

Fungsi utama karbohidrat adalah menyediakan energi bagi tubuh. Karbohidrat merupakan sumber energi utama bagi seluruh penduduk dunia karena relatif terjangkau dan mudah didapatkan.Setiap gram karbohi drat menghasilkan 4 Kkal. Keberadaan karbohidrat di dalam tubuh, sebagian ada pada sirkulasi darah sebagai glukosa, sebagian terdapat pada hati dan jaringan otot sebagai glikogen, dan sebagian lagi sisanya diubah menjadi lemak untuk kemudian disimpan sebagai cadangan energi di dalam jaringan lemak.

b. Sebagai Pemberi Rasa Manis pada Makanan

Fungsi karbohidrat berikutnya adalah memberi rasa manis pada makanan, khususnya monosakarida dan disakarida. Gula tidak mempunyai rasa manis yang sama, dan Fruktosa adalah jenis gula yang paling manis.

c. Sebagai Penghemat Protein

Bila kebutuhan karbohidrat makanan tidak mencukupi, maka protein akan digunakan sebagai cadangan makanan untuk memenuhi kebutuhan energi dan mengalahkan fungsi utamanya sebagai zat pembangun. Hal ini berlaku sebaliknya, jika kebutuhan karbohidrat tercukupi, maka protein hanya akan menjalankan fungsi utamanya sebagai zat pembangun.

d. Sebagai Pengatur Metabolisme Lemak

Karbohidrat mencegah terjadinya oksidasi lemak yang tidak sempurna yang dapat menghasilkan bahan-bahan keton yang dapat berbahaya

e. Membantu Pengeluaran Feses

Karbohidrat dapat membantu proses pengeluaran feses dengan cara mengatur peristaltik usus, hal ini didapat dari selulosa dalam serat makanan yang berfungsi mengatur peristaltik usus. Serat pada makanan dapat membantu mencegah kegemukan, kanker usus besar, diabetes mellitus, dan jantung koroner yang berkaitan dengan kolesterol tinggi. Laktosa yang terdapat pada susu dapat membantu penyerapan kalsium. Keberadaannya yang tinggal lebih 
lama dalam saluran cerna memberikan keuntungan karena menyebabkan pertumbuhan bakteri baik.

\section{3.) Jenis-Jenis Karbohidrat}

a. Monosakarida (karbohidrat sederhana)

Monosakarida merupakan jenis karbohidrat sederhana yang terdiri dari 1 gugus cincin. Contohnya glukosa (misalnya buah buahan, sayuran, sirup jagung), fruktosa (misalnya buah buahan dan madu), dan galaktosa (sebagai hasil proses pencernaan laktosa dalam tubuh).

b. Disakarida (karbohidrat sederhana)

Disakarida merupakan jenis karbohidrat yang banyak dikonsumsi oleh manusia di dalam kehidupan sehari-hari. Setiap molekul disakarida akan terbentuk dari gabungan 2 molekul monosakarida. Contoh disakarida yang umum digunakan dalam konsumsi sehari-hari adalah sukrosa yang terbentuk dari gabungan 1 molekul glukosa dan fruktosa dan juga laktosa yang terbentuk dari gabungan 1 molekul glukosa \& galaktosa.

c. Karbohidrat Kompleks

Karbohidrat kompleks merupakan karbohidrat yang terbentuk oleh hampir lebih dari 20.000 unit molekul monosakarisa terutama glukosa. Di dalam ilmu gizi, jenis karbohidrat kompleks yang merupakan sumber utama bahan makanan yang umum dikonsumsi oleh manusia adalah pati. Pati yang juga merupakan simpanan energi di dalam sel-sel tumbuhan ini berbentuk butiranbutiran kecil mikroskopik. Di alam, pati banyak terkandung dalam beras, gandum, jagung, biji-bijian seperti kacang merah atau kacang hijau dan banyak juga terkandung di dalam berbagai jenis umbi-umbian seperti singkong, kentang atau ubi.

d. Pencernaan Karbohidrat

Pencernaan karbohidrat dimulai dimulut dengan bantuan enzim amilase, dilambung pencernaannya tidak ada, proses selanjutnya diusus halus, dimana karbohidrat dicerna dengan bantuan enzim maltase, sukrase dan laktase. Hasil akhir pencernaan karbohidrat ini meliputi glukosa, fruktosa, dan galaktosa. Sisa-sisa karbohidrat yang tidak dicerna, didalam usus besar mengalami fermentasi. Makanan pokok manusia dibumi ini sebagian besar merupakan karbohidrat, contohnya nasi, jagung, umbi-umbian, pasta, roti, sagu, mie.

\section{Lemak}

1.) Pengertian Lemak

Lemak atau lipid adalah senyawa organik yang larut dalam pelarut non polar seperti etanol, kloroform dan benzena, tetapi tidak larut dalam air. Lemak mengandung karbon, hidrogen dan oksigen. Walaupun elemen-elemen ini juga 
menyusun karbohidrat, perbandingan oksigen terhadap karbon dan hidrogen lebih rendah pada lemak. Karena lemak lebih sedikit mengandung oksigen, kalori yang dihasilkannya dua kali lebih banyak daripada karbohidrat dalam jumlah yang sama. Tubuh banyak mendapat lemak dari makanan yang dikonsumsi, tetapi tubuh juga membentuk beberapa lemak.

2.) Klasifikasi lemak

a. lemak sederhana, lemak sederhana terdiri dari lemak netral dan ester lemak dengan alkohol berberat molekul tinggi;

b. lemak majemuk, lemak majemuk terdiri dari fosfolipida dan lipoprotein; dan

c. lemak turunan, lemak turunan terdiri dari asam lemak, sterol, dan lain-lain (vitamin A,D,E dan K)

3.) Jenis-Jenis Lemak

a. Trigliserida, sekitar $95 \%$ lemak dalam makanan merupakan trigliserida, dan trigliser ida merupakan bentuk lemak utama yang disimpan dalam tubuh.

Struktur dasar trigliserida terdiri atas satu molekul gliserol yang tergabung dengan tiga rantai asam lemak.

b. Lemak Trans, dalam satu proses yang disebut hidrogenasi, produsen makanan menambahkan hidrogen ke dalam minyak tak jenuh ganda untuk membuatnya padat dalam suhu ruangan.

c. Fosfolipid adalah sekelompok lemak majemuk yang menyerupai trigliserida. Fosfolipid mengandung satu molekul gliserol, tetapi hanya mengandung dua rantai asam lemak. Bukannya mengikat asam lemak ketiga, fosfolipid malah mengikat kelompok fosfat dan senyawa lain yang mengandung nitrogen. Fosfolipid secara alamiah terkandung hampir dalam semua makanan.

d. Sterol, sterol adalah molekul kompleks yang atom-atom karbonnya membentuk empat struktur siklik yang tergabung dalam berbagai rantai samping. Sterol tidak mengandung molekul gliserol atau asam lemak. Salah satu contoh sterol adalah kolesterol.

4.) Fungsi Lemak

a. Lemak sebagai bahan bakar

b. Lemak merupakan bentuk energi terkonsentrasi yang memberikan kalori sebesar $9 \mathrm{kal} /$ gram - dua kali jumlah kalori yang dihasilkan oleh karbohidrat dan protein. Akan tetapi, lemak bukanlah sumber bahan bakar pilihan bagi tubuh karena lebih sulit dimetabolisasi.

c. Memberdayakan vitamin, Lemak dalam makanan mempermudah penyerapan vitamin larut lemak A, D, E dan $\mathrm{K}$.

d. Memasok asam lemak esensial. Lemak dalam makanan memberikan asam lemak esensial : asam linoleat dan asam alfa-linolenat. Kedua asam lemak ini dianggap esensial karena tidak dapat dibuat oleh tubuh. Asamlemak esensial 
penting untuk merawat kult yang sehat, mendukung pertumbuhan yang normal pada anak-anak, dan mempertahankan kebugaran fungsi imun.

e. Lapisan bantalan manusia, Jaringan lemak menjadi bantalan dan melindungi organ vital dengan memberikan lapisan lemak penyokong untuk meredam benturan mekanik. Contoh organ yang disokong oleh lemak adalah mata dan ginjal.

f. Penyekat tubuh, Lapisan lemak menyekat kulit, membantu melindungi tubuh dari panas atau dingin yang berlebihan. Selubung jaringan lemak yang mengelilingi serabut saraf menjadi insulator untuk membantu penghantaran impuls saraf.

g. Melumasi jaringan tubuh

h. Tubuh manusia membuat minyak di dalam kelenjar sebasea. Sekresi dari kelenjar sebasea melumasi kulit untuk memperlambat hilangnya cairan tubuh ke lingkungan luar.

\section{Protein}

1.) Pengertian Protein

Protein adalah molekul makro yang mempunyai berat molekul antara lima ribu hingga beberapa juta. Protein terdiri atas rantai-rantai panjang asam amino yang terikat satu sama lain dalam ikatan peptide. Asam amino terdiri atas unsur-unsur karbon, hidrogen, oksigen dan nitrogen. Beberapa asam amino disamping itu juga mengandung unsur-unsur fosfor, besi, sulfur, iodium, dan kobalt. Sedangkan unsur nitrogen adalah unsur utama protein, karena terdapat didalam semua protein akan tetapi tidak terdapat didalam karbohidrat dan lemak.

2.) Sintesis Protein

Protein mempunyai peranan penting dalam organisasi struktural dan fungsional dari sel. Protein struktural menghasilkan beberapa komponen sel dan beberapa bagian diluar sel seperti kutikula, serabut dan sebagainya. Protein fungsional (enzim dan hormon) mengawasi hampir semua kegiatan metabolisme, biosintesis, pertumbuhan, pernapasan dan perkembangbiakan dari sel. Sintesis protein adalah proses pembentukan protein dari monomer peptida yang diatur susunannya oleh kode genetik. Sintesis protein dimulai dari anak inti sel, sitoplasma dan ribosom. DNA tidak dapat secara langsung menyusun rantai polipeptida karena harus melalui Ribose Nucleic Acid (RNA). Seperti yang telah kita ketahui bahwa DNA merupakan bahan informasi genetik yang dapat diwariskan dari generasi ke generasi. DNA merupakan susunan kimia makromolekular yang komplek, yang terdiri dari tiga macam molekul yaitu : Gula pentose yang dikenal sebagai deoksiribosa, Asam pospat, dan Basa nitrogen, dibedakan atas dua tipe dasar yaitu: pirimidin terdiri dari sitosin $(\mathrm{S})$ dan timin $(\mathrm{T})$, dan purin yang terdiri dari adenine $(A)$ dan guanine $(G)$. 


\section{3.) Struktur Protein}

a. Struktur primer

Struktur primer adalah urutan asam-asam amino yang membentuk rantai polipeptida. Struktur primer protein merupakan urutan asam amino penyusun protein yang dihubungkan melalui ikatan peptida (amida). Urutan asam amino menentukan fungsi protein.

b. Struktur sekunder

Struktur sekunder protein bersifat reguler, pola lipatan berulang dari rangka protein. Dua pola terbanyak adalah alpha helix dan beta sheet. Struktur sekunder protein adalah struktur tiga dimensi lokal dari berbagai rangkaian asam amino pada protein yang distabilkan oleh ikatan hidrogen.

c. Struktur tersier

Struktur tersier protein adalah lipatan secara keseluruhan dari rantai polipeptida sehingga membentuk struktur 3 dimensi tertentu.Sebagai contoh, struktur tersier enzim sering padat, berbentuk globuler. Struktur tersier yang merupakan gabungan dari aneka ragam dari struktur sekunder.

d. Struktur kuartener

Beberapa protein tersusun atas lebih dari satu rantai polipeptida. Struktur kuartener menggambarkan subunit-subunit yang berbeda dipakai bersamasama membentuk struktur protein.

4.) Fungsi Protein

a. Enzim, semua enzim yang teah diamati sampai saat ini adalah protein dan aktivitas katalitiknya bergantung pada integritas strukturnya sebagai protein. Enzim mempunyai berat molekul 12.000-lebih dari 1.000.000, karena itu enzim berukuran amat besar dibanding dengan substrat atau gugus fungsional.

b. Protein Transpor: Hemoglobin dan Mioglobin. Protein yang terdapat pada hemoglobin dan mioglobin berfungsi dalam pengikatan oksigen, pengangkutan oksigen dan fotosintesis. Hemoglobin juga mengangkut $\mathrm{H}+\mathrm{dan}$ $\mathrm{CO} 2$. Selain membawa oksigen dari paru-paru ke jaringan, hemoglobin juga membawa $\mathrm{H}+$ dan $\mathrm{CO} 2$ dari jaringan ke paru-paru dan ginjal untuk dieksresikan. Dalam sel, bahan bakar organic dioksidasi oleh mitokondria membentuk CO2, air dan zat- lain. Pembentukan CO2 meningkatkan kadar $\mathrm{H}+$ di dalam jaringan karena hidrasi $\mathrm{CO} 2$ menghasilkan $\mathrm{H} 2 \mathrm{CO} 3$, suatu asam lemah yang terdisosiasi membentuk $\mathrm{H}+$ dan $\mathrm{HCO} 3$.

c. Protein Pengatur: Hormon, Hormon adalah hasil sekresi kelenjar-kelenjar spesifik yang akan bekerja pada sel-sel di dekatnya dalam suatu jaringan tertentu, di samping pada sel di mana dia disintesis. Contohnya : Hormon Pertumbuhan, Insulin, Paratiroid Hormon .

d. Protein Kontraktil. Banyak protein yang berperan sebagai filamen, kabel, lembaran penyanggah untuk memberikan struktur biologi atau kekuatan. 
Massa serat otot yang segar disusun $75 \%$ dari air dan lebih dari $20 \%$ protein. Dua protein utama otot adalah aktin dan miosin.

e. Protein Struktural . $\alpha$-Keratin adalah protein serat utama yang dibuat oleh sel epidermis. $\alpha$ - Keratin memberikan perlindungan eksternal bagi vertebrata. Protein ini menyusun hampir seluruh berat kering dari rambut, wol, sayap, kuku,cakar, duri, sisik, tanduk, kuku kuda, kulit penyu. Fibrinogen dan Trombin adalah protein yang terlibat dalam proses hemostatis. Hemostatis adalah peristiwa penghentian perdarahan yang terjadi setelah terputusnya keutuhan vaskuler.

f. Protein Nutrien dan Penyimpan. Protein nutrien dan penyimpan terdapat pada: Biji tumbuhan menyimpan protein nutrient yang dibutuhkan untuk pertumbuhan embrio tanaman. Contohnya: protein biji gandum, jagung, dan beras, albumin, protein nutrient pada putih telur, Kasein, protein utama pada susu.

\section{Vitamin}

1.) Pengertian Vitamin

Vitamin adalah senyawa organik yang tersusun dari karbon, hidrogen, oksigen, dan terkadang nitrogen atau elemen lain yang dibutuhkan dalam jumlah kecil agar metabolisme, pertumbuhan dan perkembangan berjalan normal. Jenis nutrien ini merupakan zat-zat organik yang dalam jumlah kecil ditemukan pada berbagai macam makanan. Vitamin tidak dapat digunakan untuk menghasilkan energi.

2.) Klasifikasi Vitamin

Vitamin dapat dipilah menjadi 2 kelompok yaitu kelompok yang larut dalam lemak dan yang larut dalam air. Vitamin yang larut dalam lemak terdiri dari vitamin A, D, E dan K. Sedangkan vitamin yang larut dalam air terdiri dari vitamin B kompleks dan vitamin C. Vitamin larut-lemak dalam takaran yang besar akan berbahaya bagi tubuh karena jenis vitamin ini tidak dapat diekskresikan keluar dan akan tersimpan di dalam tubuh. Sedangkan vitamin larut-air dapat diekskresikan kedalam urine sehingga takaran yang besar tidak membahayakan kesehatan. Vitamin larut lemak:

a. Vitamin A

karoten merupakan precursor vitamin A. Zat ini merupakan pigmen kuning yang terdapat pada banyak tanaman, khususnya yang berwarna kuning, merah atau hijau gelap. Hewan, termasuk manusia, dapat mengkonversikan karoten pada makanannya menjadi vitamin A. Manusia memperoleh vitamin A sebagian dari makanan hewani di mana vitamin tersebut sudah terbentuk dan sebagian lagi diperoleh dari karoten yang diperoleh dari sayuran, buah-buahan dan berbagai produk hewani. Makanan yang kaya akan karoten mencakup sayuran, khususnya yangberdaun gelap seperti tomat dan wortel, serta buah- 
buahan terutama yang berwarna kuning seperti mangga. Kelebihan vitamin A mengakibatkan: osteoporosis, cacat lahir, toksisitas hati (keracunan hati), kesulitan melahirkan, kelahiran prematur. Pada kekurangan vitamin A dapat menyebabkan: gangguan penglihatan (Xeropthalmia), kerusakan jaringan epitel, gangguan pertumbuhan, daya tahan tubuh yang rendah.

b. Vitamin D

Tergolong vitamin yang mudah larut dalam lemak dan merupakan prahormon jenis sterol. Vitamin D merupakan kelompok senyawa sterol yang terdapat di alam, terutama pada hewan, tetapi juga ditemukan ditumbuhan maupun ragi. Vitamin D terdiri dari dua jenis, yaitu vitamin $\mathrm{D}^{2}$ (ergokalsiferol) dan vitamin $\mathrm{D}^{3}$ (kholekalsiferol). Ergokalsiferol biasanya terdapat dalam steroid tanaman, sedangkan kholekalsiferol terdapat pada hewan. Kedua jenis vitamin D tersebut memiliki struktur kimia berbeda, namun fungsinya identik. Vitamin D sudah terbentuk sebelumnya, ditemukan di dalam telur, mentega serta ikan yang berlemak. Minyak dari ikan Cod merupakan sumber yang sangat kaya akan vitamin D. Margarin yang berasal dari minyak kelapa sawit menjalani fortifikasi artifisial dengan vitamin D. Akibat kekurangan vitamin D adalah gigi akan lebih mudah rusak, otot mengalami kejang-kejang, pertumbuhan tulang tidak normal yang biasanya betis kaki akan membentuk huruf $\mathrm{O}$ atau $X$. Dampak dan akibat kelebihan vitamin D bisa meningkatkan resiko keracunan bahkan resiko kematian. Overdosis terhadap penggunaan vitamin D memiliki efek samping yang belum banyak diketahui. Seperti kelemahan otot, sakit kepala, tuli, kehilangan nafsu makan, mual, kelelahan, muntah, nyeri tulang, rasa haus dan tekanan darah tinggi.

c. Vitamin E

Vitamin E, dibutuhkan oleh tubuh untuk pertumbuhan dan perkembangan Vitamin E merupakan salah satuf aktor yang larut dalam lemak. Sumber Vitamin E, banyak terdapat dalam bahan makanan. Sumber vitamin E yaitu: minyak gandum/jagung, sayuran, hati, telur, mentega, susu, daging, dan terutama dari tauge. Minyak kelapa dan zaitun mengandung sedikit vitamin E. Kebanyakan makanan berminyak juga mengandung vitamin E. Buah-buahan yang mengandung vitamin E meliputi: alpukat, biji bunga matahari, tomat.

d. Vitamin K

Vitamin larut lemak yang dinamakan vitamin K (dari koagulation) berhasil diisolasi. Faktor ini merupakan kelompok senyawa yang terdiri atas filokinon yang terdapat dalam tumbuh-tumbuhan dan menakinon yang terdapat dalam minyak ikan dan daging. Sumber Vitamin K, Sumber utama vitamin K adalah hati, sayuran daun yang berwarna hijau, kacang buncis, kacang polong, kol dan brokoli. Semakin hijau daun-daunan semakin tinggi kandungan vitamin $\mathrm{K}$-nya. Bahan makanan lain yang mengandung vitamin $\mathrm{K}$ dalam jumlah yang 
lebih kecil adalah susu, daging, telur, buah-buahan, dan sayuran lain. Sumber penting vitamin $\mathrm{K}$ lain adalah flora bakteri dalam usus halus (jejunum dan ileum). Kekurangan vitamin K menyebabkan darah tidak dapat menggumpal, sehingga bila ada luka atau pada operasi terjadi perdarahan. Kekurangan terjadi bila ada gangguan arsorbsi lemak. Kekuranganvitamin $\mathrm{K}$ bisa juga terjadi bila seseorang mendapat antibiotika sedangkan tubuhnya kurang mendapat vitamin $\mathrm{K}$ dari makanan. Kelebihan vitamin $\mathrm{K}$ hanya bisa terjadi bila vitamin $\mathrm{K}$ diberikan dalam bentuk berlebihan berupa vitamin $\mathrm{K}$ sintetik menadion. Gejala kelebihan vitamin K adalah hemolisis sel darah merah, sakit kuning dan kerusakan pada otak.

e. Vitamin C

Sumbernya: Sayur-sayuran seperti brokoli, kembang kol, kubis, dan paprika merah, cabai rawit, bayam mentah, sawi, seledri dan mentimum Nah, sekarang sudah paham kan sayuran apa saja yang mengandung vitamin $\mathrm{C}$, sehingga kebutuhan vitamin $\mathrm{C}$ alami anda tidak hanya dari buah jeruk saja.Buah yang banyak vitamin $\mathrm{C}$ antara lain pepaya, stroberi, jeruk dan kiwi, jambu biji, kelengkeng, melon, anggur, mangga, nanas, pisang dan alpukat.

Vitamin larut air:

a. Vitamin B1 (Tiamin), Sumber: Nasi, roti, sereal, tepung terigu, makanan laut seperti udang, kepiting atau kerang. Fungsi: Mengubah zat karbohidrat dalam makanan menjadi energi. Kekurangan vitamin B1 yang berat menyebabkan beri-beri ditandai dengan kelainan saraf, otak dan jantung.

b. Vitamin B2 (Riboflavin) : Sumber: Susu, keju, ayam, brokoli, bayam, jamur. Fungsi: Menjaga kesehatan mata dan kulit. Gejala kekurangan vitamin B2 adalah kepekaan terhadap cahaya berkurang, sudut bibir pecah-pecah, muncul gangguan kulit di sekitar hidung dan bibir.

c. Vitamin B3 (Niasin) : Sumber: Padi-padian, kacang-kacangan, daging sapi, jamur. Fungsi: Untuk kesehatan kulit, meningkatkan nafsu makan, memperbaiki sistem pencernaan serta membantu mengubah makanan menjadi energi. Gejala dan tanda kekurangan vitamin B3 adalah kulit gampang rusak, lidah jadi licin, mudah terserang diare atau sering bingung.

d. Vitamin B5 (Pantothenic Acid) : Sumbernya Ayam, ikan sarden, alpukat, semangka.Fungsi: Bersama-sama dengan jenis vitamin B lainnya, vitamin B5 berguna dalam proses pemecahan lemak, protein, karbohidrat menjadi energi. Manfaat lainnya adalah untuk pembentukan sel darah merah dan membuat vitamin D. 
e. Vitamin B6 (Piridoksin) : Sumber: Daging unggas, ikan, sapi, kentang, tomat, pisang, buah yang berwarna ungu dan sayuran hijau.Fungsi: Diperlukan dalam proses asam amino dan lemak.Kelebihan konsumsi vitamin B6 dapat menyebabkan kerusakan saraf secara permanen. Kekurangan vitamin B6 pada bayi dapat menyebabkan kejang dan anemia sedangkan pada dewasa akan timbul dermatitis, kerusakan saraf (neuropati) dan kebingungan.

f. Vitamin B7 (Biotin) : Sumber: Daging ikan salmon, telur, susu, sereal, pisang dan kacang tanah.Fungsi: Membantu dalam proses pemecahan lemak, protein menjadi energi yang akan digunakan oleh tubuh.

g. Vitamin B9 (Folat) : Sumber: Susu dan produk olahan susu, bit, hati, melon dan sayuran berdaun hijau.Fungsi: Bertugas agar sel-sel pada tubuh berkembang dengan benar, membentuk sel darah merah dan mencegah kerusakan saraf pada janin. Gejala dan tanda kekurangan vitamin B9 menghasilkan anemia makrositik, dan peningkatan kadar homocysteine. Kekurangan pada wanita hamil dapat menyebabkan bayi lahir cacat.

h. Vitamin B12 (Kobalamin) : Sumbernya daging sapi, daging ikan, hati, telur, susu, kedelai dan rumput laut.Fungsi: Mengubah karbohidrat, protein dan lemak menjadi energi, menjaga sel darah merah tetap sehat, melindungi sel saraf, mencegah penyakit jantung, dan mencegah penyusutan otak yang dapat menyebabkan daya ingat menurun.Gejala dan tanda kekurangan vitamin B12 meliputi gangguan sistem saraf, menurunkan daya ingat, mudah bingung dan murung, mudah mengalami delusi (berkhayal), lelah, hilang keseimbangan, refleks menurun, mati rasa, menimbulkan gangguan pendengaran, menyebabkan gejala anemia, hilang nafsu makan, diare, menimbulkan gangguan pembentukan sel saraf, mengakibatkan kerusakan sistem saraf.

\section{Mineral}

1.) Pengertian Minereal

Mineral merupakan komponen inorganik yang terdapat dalam tubuh manusia. Sumber paling baik mineral adalah makanan hewani, kecuali magnesium yang lebih banyak terdapat di alam makanan nabati.

2.) Jenis Mineral

a. Mineral Organik yaitu mineral yang dibutuhkan serta berguna bagi tubuh kita, yang dapat kita peroleh melalui makanan yang kita konsumsi setiap hari seperti nasi, ayam, ikan, telur, sayur-sayuran serta buah-buahan, atau vitamin tambahan.

b. Mineral anorganik yaitu mineral yang tidak dibutuhkan serta tidak berguna bagi tubuh kita.Contohnya:Timbal Hitam (Pb), Iron Oxide (Besi Teroksidasi), 
Mercuri, Arsenik, Magnesium, Aluminium atau bahan-bahan kimia hasil dari resapan tanah dan lain.

c. Mineral Makro yaitu mineral yang dibutuhkan tubuh dalam jumlah lebih dari $100 \mathrm{mg}$ sehari.

d. Mineral Mikro yaitu kebutuhannya kurang dari $100 \mathrm{mg}$ sehari.

\section{Air}

Air atau cairan tubuh merupakan bagian utama tubuh, 55-60\% dari berat badan orang dewasa atau $75 \%$ pada bayi merapan cairan tubuh. Semakin bertambah umur cairan tubuh semakin berkurang, dan cairan tubuh laki-laki lebih banyak dari wanita karena kandungan otot. Ketidakseimbangan cairan \& elektrolit terjadi bila kehilangan dalam jumlah banyak sekaligus misalnya muntah, diare, diaphoresis, luka bakar,dan lainlain. 


\section{DAFTAR PUSTAKA}

1. Alam, S., \& Karini, T.A. (2020) Islamic Parenting "Pola Asuh Anak: Tinjauan Perspektif Gizi Masyarakat".

2. Mardalena, I., \& Suryani, E. 2016. Modul Bahan Ajar Cetak Keperawatan Ilmu Gizi (I st ed.): 3-21. Jakarta Selatan: Kementrian Kesehatan Republik Indonesia.

3. Almatsier, Sunita. 2001. Prinsip Dasar Ilmu Gizi. Jakarta : PT. Gramedia Pustaka Umum

4. Budiyanto,Agus Krisno.2001. Dasar-Dasar Ilmu Gizi.Malang:UMM Pres

5. Achmad. 2000, Penuntasan Masalah Gizi Kurang Gizi. In Widya Karya Nasional Pangan dan Gizi VI, Jakarta : Lembaga Ilmu Pengetahuan Indonesia. 